\title{
Implementation Of Order E-Points As A Strengthening Implementation Of Character EducationAt State Vocational High School 1 Wonoasri
}

\author{
Wiwik Wiyati \\ Headmaster of State Vocational High School 1 Wonoasri, Madiun, Jawa Timur, 63157, Indonesia \\ wiwik.wiyati17@gmail.com \\ *Corresponding Author: wiwik.wiyati17@gmail.com | Phone Number: 081359861998
}

\begin{abstract}
Character education is needed today by industry in building a work culture to increase productivity. State vocational high school 1 Wonoasri as a vocational education that prepares graduates to be ready to work has made efforts to strengthen character education through ketarunaan education. Ketarunaan education aims to instill the character values and nationalism of students. E-points or electronic points are points that can be inputted digitally and stored in a database.The study was aimed: 1) to describe the application of order e-points in the implementation of strengthening character education at state vocational high school 1 Wonoasri ; 2) to describe the significance of the effect of the application of order e-points on changes in the behavior of students at state vocational high school 1 Wonoasri. The data taken are class X and class XI in the period July to December 2018 and January to December 2019. Specifically, class XI data is taken when students have not implemented Fieldwork Practices starting in October each year. The results of the data from the e-points application note that: 1) the total number of students in class X and class XI in 2018 amounted to 1186 people, who violated the rules of discipline of 531 people or $44.77 \%$. In 2019, there were 1186 students who committed violations amounting to 133 people or $11.21 \%$. The number of students who committed violations in 2019 when compared to 2018 decreased by $33.56 \%$; 2) The application of e-points has a significant impact on changes in the attitudes and character of students towards the better. The indicator is a decrease in the number of violations committed by students.
\end{abstract}

Keywords: cadets of education; e-points; Industrial work culture

\section{Introduction}

Education is a process of forming and developing human beings through the experiences they experience. According to the large Indonesian dictionary, education is a process or stage in changing attitudes and ethics and behavior of a person or group of people in improving the human mindset through teaching and training as well as educational actions. Through the events and events experienced by humans, there are patterns of changes in behavior and patterns of thinking about the events they experience as an educational process. More clearly, it is stated in Law Number 20 of 2003 concerning the national education system that the goal of education is expected to be able to develop the potential that is owned so that people who believe and fear God Almighty, have noble character, are healthy, knowledgeable, capable, creative, be independent, and become democratic and responsible citizens. The ideal character of human resources that is expected shows dominant facts which are inversely proportional to reality on the ground. Often we witness the phenomenon of deviation which has become a strategic issue in the world of education from various mass and electronic media sources carried out by school stakeholders. Ironically, the news of this irregularity has become public consumption which is imaged massively and destructively to the point where it sags and tore apart noble values and culture as the great foundation in the world of education.

The news about illegal levies, misuse of BOS funds and corruption by school principals have made public trust at the lowest level. Coupled with the variety of industrial acts of teachers and education personnel such as physical and sexual violence, skipping work hours, and acting dishonestly in helping students in the UN conducted by the teacher further tarnish Tut Wuri Handayani's alma mater. Equivalent to three money with deviations from school principals and GTK, at the student level, the moral and social degradation that occurs is getting worse, starting from rampant brawls between students, direct violations, illegal racing, stealing, alcohol, drugs, free sex, and pornography are a series of behaviors that currently This has surfaced among the younger generation of students (Suhardi, 2015). Almost every day we hear about events related to student delinquency happening. These various deviations in the world of education are 
indicators of the beginning to deteriorate the character and culture of Indonesian people who are at their lowest point.

For this reason, the government has sought to focus on character education since 2015 with the issuance of Permendikbud Number 23 of 2015 concerning character development, Next issued Presidential Regulation Number 87 of 2018 concerning strengthening character education and Permendikbud Number 20 of 2018 concerning strengthening character education in formal education unit. Strengthening character education is an educational movement under the responsibility of an education unit to strengthen the character of students through harmonization of heart, feeling, thinking, and sports with involvement and collaboration between educational units, families and communities. The implementation of character education can be carried out by applying the values of Pancasila, namely; religious values, honesty, tolerance, discipline, hard work, creative, independent, democratic, curiosity, national spirit, love for the country, communicative, fond of reading, caring for the environment, caring socially, and being responsible.

Before the echo of strengthening character and character education, in 2013, State vocational high school 1 Wonoasri had realized the importance of character education for students by implementing education for all students. This is based on the implementation of the 2013 curriculum which in general emphasizes changes in attitudes and behavior in the learning process. In addition, based on an evaluation of the labor recruitment process from the industry held at State vocational high school 1 Wonoasri, soft skills in the form of character education, manners, courtesy, discipline, work ethic, and responsibility are assessments that have a large enough priority. This is evidenced by the results that passed the administrative selection and took the general and psychological tests of nearly 70 students, who passed the interview test no less than 12 students.

Every year the Ketarunaan program is always evaluated on the implementation and impact of changes in attitude and behavior. Broadly speaking, the extreme delinquency of students, such as before the implementation of the ketarunaan program, has significantly reduced. This shows a fairly good pattern of changes in attitude and behavior. However, there are still several behaviors that require continuous followup and assistance. Especially in the daily habits of learning, including permission to leave learning activities due to other activities, going out and about in class during learning activities, being late in collecting assignments, not throwing garbage in a sorted place. Following up on these problems, innovative and creative efforts are needed to be able to provide motivation and assistance to these students. One of the efforts made is to develop electronic application points (e-points) for student order. This is to familiarize students through continuous supervision and assistance by all school members. The activity of all school members in an active role in providing assistance to students by utilizing the e-points application is expected to have a fundamental change in student behavior. We will describe the implementation of the use of student discipline e-points in the form of scientific work in the form of best practices with the title Implementation of Order E-Points as Implementation of Strengthening Character Education at state vocational high school 1 Wonoasri.

\section{Materials And Methods}

The data taken are class X and class XI in the period July to December 2018 and January to December 2019. Specifically, class XI data is taken when students have not implemented Fieldwork Practices (PKL) starting in October each year. E-points or electronic points are points that can be inputted digitally and stored in a database. Hidayat (2009) explained that the points inputted are points of violation and achievement points of students. In the e-points system, the teacher does not directly give punishment to students, but through stages based on the accumulated weight of the violations that have been committed. E-points make it easier for the order team to no longer fill out the violation books manually. E-points allow every student registered in the database to be able to view profiles along with data on violations or history of violations while being students at state vocational high school 1 Wonoasri.

Broadly speaking, the working principles of the e-points application are; data on points of violation and achievement are inputted by all school members (teachers and staff employees). It is a joint responsibility to supervise school discipline enforcement so that all school members automatically become clients of the epoints application. Data points that are sent via Android, enter the database on the server according to the name of each student to be stored in the student database locator. So that the point data and point history of students will not be lost because they have been recorded on the server computer. Data points are processed and informed back to students and stakeholders with an interest in order data points, namely; school principals, deputy principals, homeroom teachers, counseling teachers, heads of skills competencies, and to parents of students. All data processing and information delivery is carried out automatically based on the parameters / conditions set by the school. The following is a block diagram of the e-point system: 


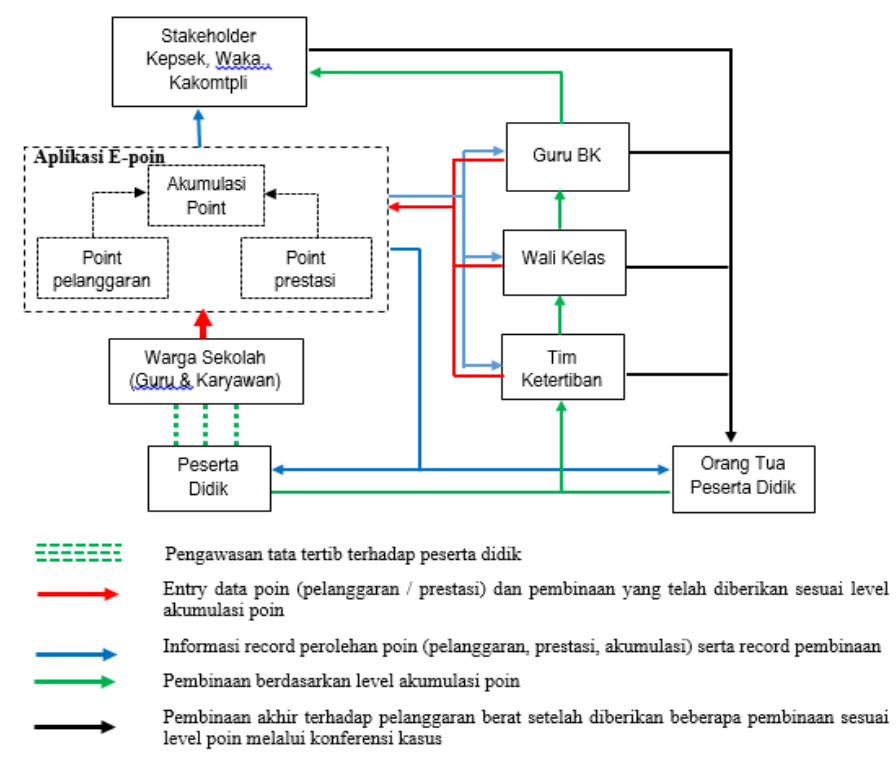

Figure 1. Block diagram of the e-point

\section{Results And Discussions}

\subsection{Implementation of E-Points of Order in the Implementation of Strengthening Character Education}

The implementation of E-Points of Order at state vocational high school 1 Wonoasri was carried out in three stages, namely; preparation, implementation, and evaluation/reporting.

1. Preparation Stage

a. The web browser-based e-points application of state vocational high school 1 Wonoasri is stored on the school server with the link: http:/ / epoin.smkn1wonoasri.sch.id/

b. The e-points application is actively used by school residents using localhost in the school wifi environment. This is because; 1) e-points are used to monitor the implementation of school order to students during learning activities at school, 2) minimize the subjectivity of teachers and employees towards students based only on "like and dislike". So that e-points can only be accessed in the school environment according to the learning time of students.

c. The formation of an order team and the distribution of their respective duties according to the stages of national development. The order team involved in accordance with the disciplinary guidelines for Vocational School students of the East Java Provincial Education Office are; Principal, Deputy Principal, Head of Expertise Competency, BK Teacher, Homeroom Teacher, and Student Team, and Teachers/Employees. The job descriptions in the implementation of this epoin are:

1. Principal: monitoring and evaluating the process of implementing the points by the Order Team, conducting final coaching for serious violations after all coaching stages have been carried out, returning students to parents after the coaching period is complete based on a point level of more than 250 points.

2. Deputy Principal: coordinating the implementation of the duties of the order team, making reports on character development in e-points, coordinating coaching at each point level, providing guidance for serious violations at the level of 151 - 249 points after the coaching period at the previous point level level has been carried out.

3. Head of Skills Competency and Counseling Teacher Coordinator: provide guidance for moderate violations at the $96-150$ level after the coaching period at the previous point level level has been carried out.

4. BK teacher: provides guidance for moderate violations at the level of 76 - 95 points after the coaching period at the previous point level has been carried out.

5. Homeroom teacher: provides guidance for moderate violations at the level of $56-75$ points after the coaching period at the previous point level has been carried out.

6. Coord. Tatib: provide coaching for moderate violations at the level of 36 - 55 points after the coaching period at the previous point level level has been carried out.

7. Tatib Team: provides guidance for moderate violations at the level of $10-35$ points. 
d. Preparation of procedures for implementing school order fostering

The procedure for implementing school order fostering is prepared to facilitate coordination of related parties in implementing school regulations. Each party involved must understand the procedure so that student order is carried out in a form that brings justice and guidance.

Table 1. Phase/stages of handling Offence

\begin{tabular}{|c|c|c|c|}
\hline No & Offense Category & Foul Score Ranges & Follow-Up \\
\hline \multirow[t]{2}{*}{1} & \multirow{2}{*}{ Minor Offense } & $10-35$ & $1^{\text {st }}$ warning (order officer) \\
\hline & & $36-55$ & $2^{\text {nd }}$ warming (order coordinator) \\
\hline \multirow{3}{*}{2} & \multirow[b]{3}{*}{ Moderate Offense } & $56-75$ & call parents to I (homeroom teacher) \\
\hline & & $76-95$ & call parents II (counseling guidanceteacher) \\
\hline & & $96-150$ & call parents III (counseling guidance coordinator) \\
\hline \multirow[t]{2}{*}{3} & \multirow[t]{2}{*}{ Serious Offense } & $151-249$ & suspension (deputy principal of education) \\
\hline & & 250-up & returned to parents (headmaster) \\
\hline
\end{tabular}

e. The epoin admin is an order team coordinated by Waka. Student. The epoin admin is tasked with preparing the application by entering the database on the master menu; violation master, reward master, class master, student master, user master, follow up master.

f. The teachers install the application on their respective androids

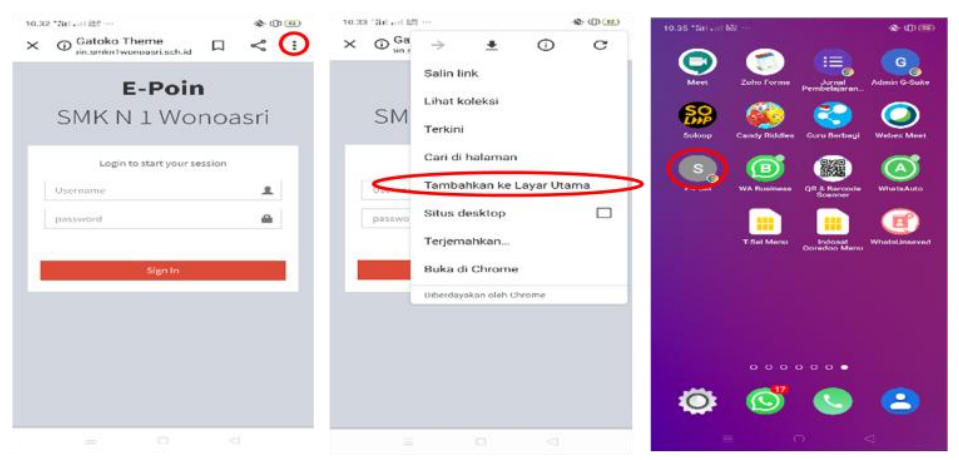

Figure 2. Installing E-point on Android via browser

Installing e-points on Android is done by opening the e-points web address http://epoin.smkn1wonoasri.sch.id/ in the android browser. Click the colon (red circle) in the upper right corner. Select add to home screen. The e-points menu will appear on the android main screen. This is to make it easier for teachers and employees to use e-points to input participant order points

2. Implementation Stages

a. The dashboard view of the e-points application corresponds to the role of the task in e-point management

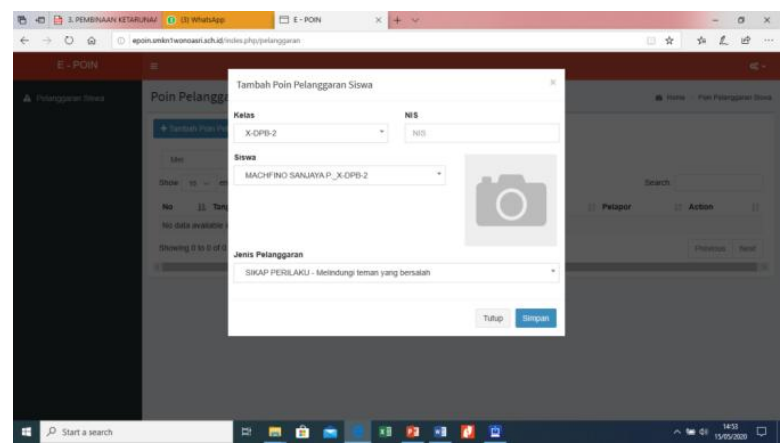

Figure 3. Display of Data Entry Violations

b. teachers and employees of state vocational high school 1 Wonoasri play an active role in supervising violations of discipline by students.

c. The teachers and employees of state vocational high school 1 Wonoasri actively report incidents of violations that have been committed by students on the epoin application in the Student Violations 
menu.

d. Award points are entered via the Student Awards by Students menu.

e. All data on reward points, violation points, accumulated points, and coaching actions can be seen in the point calculation menu.

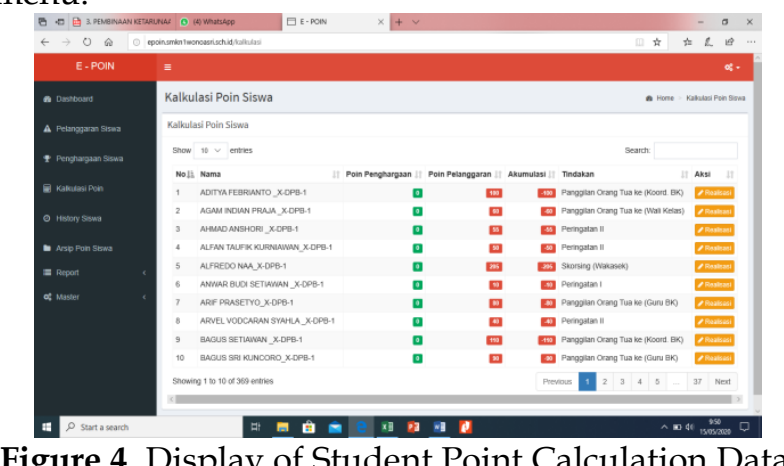

Figure 4. Display of Student Point Calculation Data

f. The Order Team, homeroom teacher, and counseling teachers pay attention to the point calculation menu display which displays point recapitation and suggestions for guidance that must be done according to the point level level. To do coaching click realization. Fill in the guidance that has been done in the realization box.

g. The Principal and Deputy Principal of the School provide guidance to the level of serious violation points.

h. Reporting

Records of the coaching that have been carried out for each type of violation are archived in the student's point archive. Reports on the report menu cannot be displayed because it is still in the process of being developed and corrected.

\section{Evaluation}

The application of e-points of order as an effort to develop character values in accordance with industry demands in the form of work culture has not been able to run optimally as expected. This is because within 2 years since the implementation of e-points, improvements and additional features in the application are still needed to be adjusted to school conditions and policies. Even so in general, the application of e-points is very helpful for always monitoring and monitoring the development of the character of students on an ongoing basis for immediate guidance and assistance. There are several benefits that can be felt in the application of order e-points at state vocational high school 1 Wonoasri, namely:

a. Reducing the incidence of immeasurable individual teacher physical action in providing guidance to violations committed by students.

b. Coaching against violations by student participants is carried out objectively based on the provisions of the established school rules and regulations. If the coaching is carried out by the teachers spontaneously, it is possible that it is influenced a lot by the "like and dislike" factor and it is not objective. Even more extreme is done without control because it is influenced by the teacher's emotion.

\subsection{The Significance of the Effect of the Implementation of Order E-Points on Changes in Student Behavior}

The character development of students in this paper is a change in behavior and attitudes as a result of coaching that has been done through the application of e-points of order. The data used to describe changes in character are; data on violations that are often committed by students, data on the number of students who commit violations at each class level, data on the number of students who have been given guidance based on the level of order points. The data used is since the implementation of e-points began, namely in the period July - December 2018 and January - December 2019. Class level data taken are class X and class XI. The types of violations discussed are the types of violations that occur most frequently.

1. Total of students 


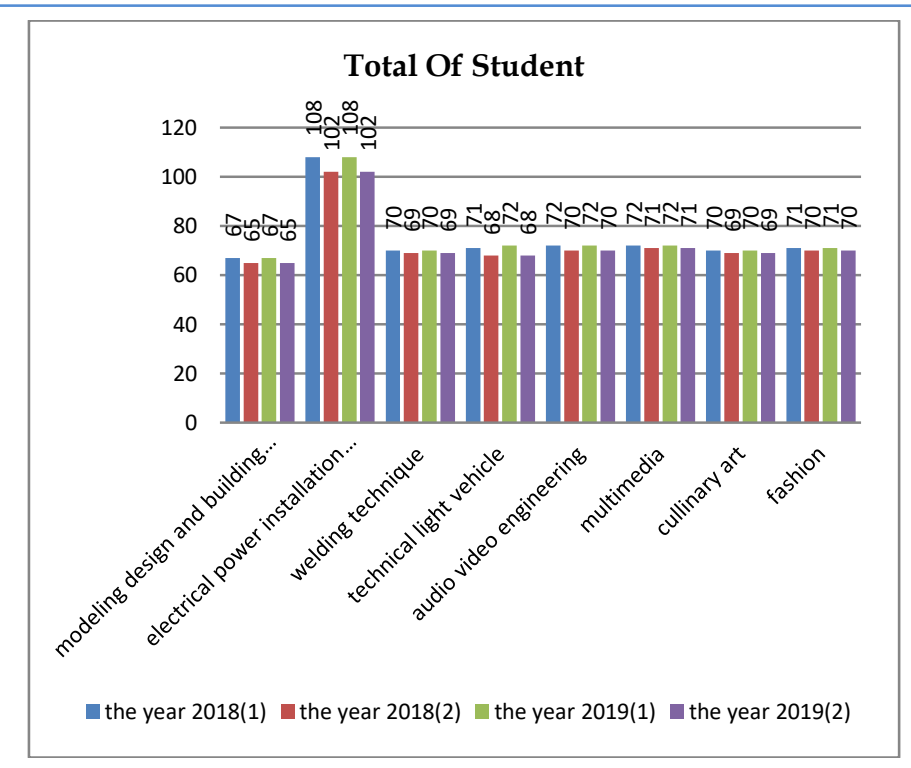

Figure 5. Data on the Total of Students

There is very little difference between the number of students in 2018 and 2019. This shows that the percentage of students who commit serious violations and result in being returned to their parents is very small.

2. Types of violations that are often committed
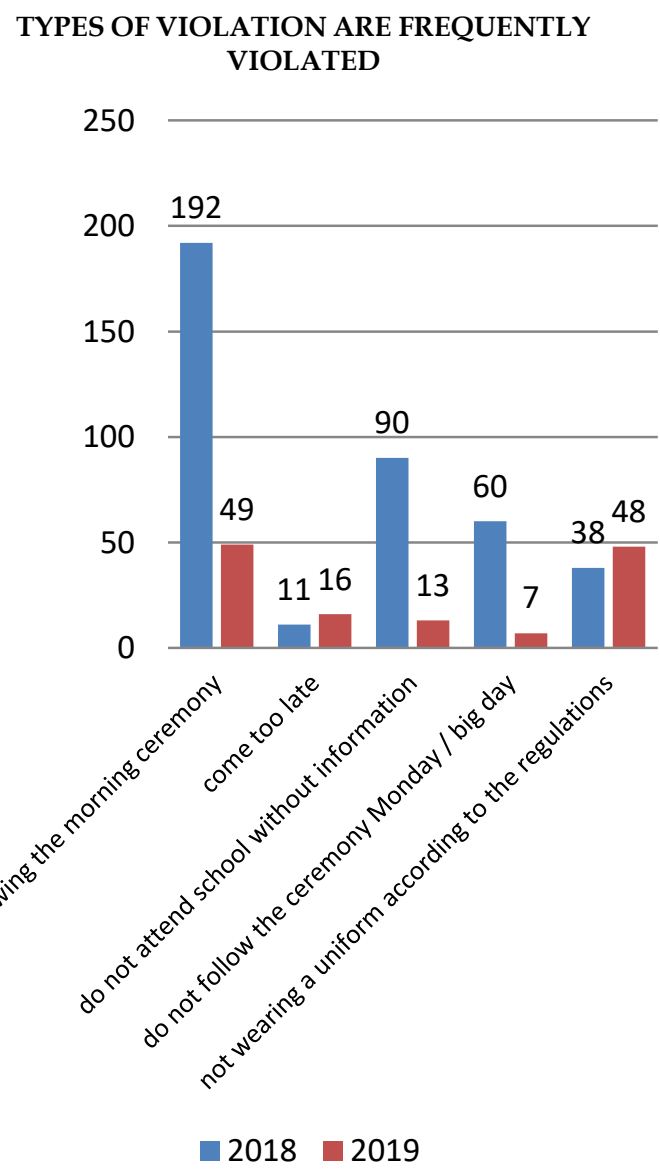

Figure 6 . Types of Frequently Committed Violations

In general, the types of violations in 2019 decreased compared to 2018. It's just that the types of violations that have increased in 2019 are not in uniform according to the provisions. 
3. Number of violations of class $\mathrm{X}$ rules of conduct in 2018 and 2019

Violation 6f The Rules 6f Class X In 2018

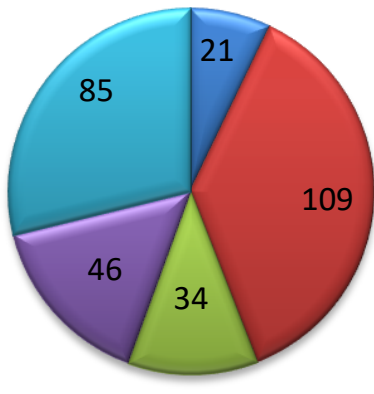

$\square$ not wearing a

uniform according

to the regulations

$\square$ not following the

morning ceremony

$\square$ do not follow the

ceremony Monday /

big day

$\square$ do not attend

school without

information

Figure 7. Total of Class X Code Violations 2018

Violation of The Rules of Class X In 2019

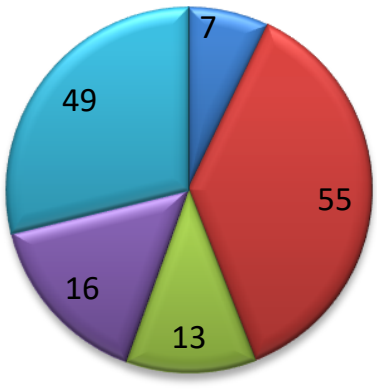

$\square$ not wearing a

uniform according

to the regulations

$\square$ not following the

morning ceremony

do not follow the

ceremony Monday /

big day

$\square$ do not attend

school without

information
come too late

Figure 8. Total of Class X Code Violations 2019

From the two data on violations of school discipline by class X students in 2018 and 2019, all types of violations experienced a significant decrease.

4. Number of class XI violations in 2018 and 2019

Violation of The Rules of Class XI In 2018

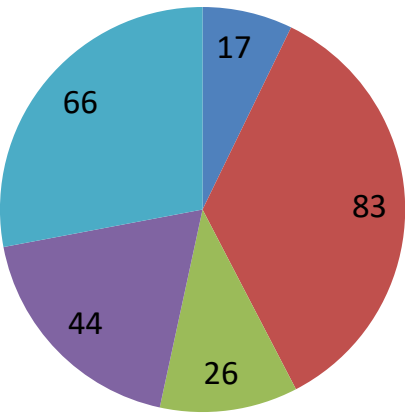

not wearing a uniform according to the

regulations

not following the

morning ceremony

do not follow the ceremony Monday /

big day

do not attend school

without information

come too late

Figure 9. Total of Class XI Code Violations in 2018 
Violation of The Rules of Class XI In 2019

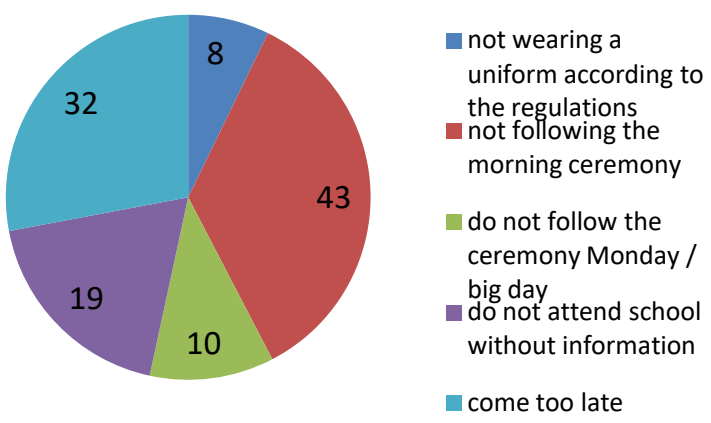

Figure 10. Total of Class XI Code Violations in 2019

From the two data on violations of school discipline by class XI students in 2018 and 2019, all types of violations experienced a significant decrease. It's just that for this class XI data, it was taken before the implementation of the Field Work Practices starting from October to March of the following year.

Based on the data exposure above, it can be concluded that the implementation of order e-points at state vocational high school 1 Wonoasrihas a positive impact on character change by decreasing the number of students who commit violations. This is in line with the theory that implementing school discipline is an effort to foster an industrial work culture as expected by the business world/industrial world, there is a need for assertiveness and guidance for violations of discipline that occur. Firm action by providing guidance can provide confidence and awareness to students that every violation committed will always have sanctions and consequences for violations of these rules.

Taking into account the violation data above, the types of violations are still dominated by not following the morning roll call and coming to school late. This may be because the morning apple program was only implemented in the 2019/2020 school year starting in July 2019 and was dominated by class X students. The large number of students who did not take part in the morning apple was probably still in the process of adjusting to daily habits at the previous education level in junior high school. Meanwhile, some of the class XI students who did not take part in the morning roll call were mostly influenced by the implementation of Field Work Practices in DU/DI, especially DU/DI which was personal and did not apply industrial work culture.

\section{Conclusion}

Based on the description of the application of e-points of order as an implementation of strengthening character education at state vocational high school 1 Wonoasri, it can be concluded that: 1) One of the activities to strengthen character education at SMK Negeri 1 Wonoasri is cadence which emphasizes the values of self-character, national values, and opportunities that are the demands of the business world / industrial world in building an industrial work culture in schools. Strengthening character values that have been implanted through taradaan, need continuous efforts in implementing these values in everyday learning activities through disciplinary enforcement of school rules ; 2) Efforts to enforce discipline on school discipline must be carried out continuously and objectively through the application of the e-point of order application. E-point of order is a point system in implementing school discipline using the application through the system mechanism in the order team in an objective and measurable manner. Coaching against violations of school discipline is carried out based on the level of points; and 3) The application of e-points has a significant impact on changes in the attitudes and character of students for the better. The indicator is a decrease in the number of violations committed by students. The application of e-points also brings benefits, including no more personal physical violence between teachers and students in coaching the violations that occur. Coaching is carried out objectively based on the level of points.

\section{Recommendation}

Even though there is a significant impact with the decrease in the number of violations against school discipline, it is possible that there are still matters that are of concern to schools for handling and repairs. For this reason, there are several recommendations to be followed up, namely: 1) It is still found that some 
students do not wear school attributes appropriately according to the provisions of school rules. There needs to be a collaboration with the school business center to provide equipment and school uniform attributes, especially for students whose uniforms and attributes are damaged or missing; 2) Types of violations that come late and do not attend the morning roll call, require more intensive coordination and cooperation with parents and homeroom teachers in providing understanding to students about the importance of discipline for the future; and 3) Development of the e-points application by adding features to monitor violations of the discipline of implementing Field Work Practices in the business/industrial world by involving industry supervisors. The e-points application can be accessed by industry supervisors in providing reports on the development of work attitudes while in the street vendors.

\section{References}

Undang-Undang Nomor 20 Tahun 2003 tentang Sistem Pendidikan Nasional

Peraturan Presiden Nomor 87 Tahun 2018 tentang Penguatan Pendidikan Karakter

Peraturan Menteri Pendidikan dan Kebudayaan Nomor 23 Tahun 2015 tentang Penumbuhan Budi Pekerti.

Peraturan Menteri Pendidikan dan Kebudayaan Nomor 20 Tahun 2018 tentang Penguatan Pendidikan Karakter di Satuan Pendidikan Formal.

Peraturan Menteri Pendidikan dan Kebudayaan Nomor 34 Tahun 2018 tentang Standar Nasional Pendidikan Sekolah Menengah Kejuruan/Madrasah Aliyah Kejuruan.

Sudrajat. Ahmad. 2010. Apa Pendidikan Karakter Itu ?. Artikel ditulis di blog pendidikan Ahmad Sudrajat tentang pendidikan. Online https: / akhmadsudrajat.wordpress.com/2010/09/15/konsep-pendidikankarakter/diakses tanggal 1 Mei 2020.

Tafsir, Ahmad. 2005. Imu Pendidikan dan Perspektif Islam. Bandung : PT. Remaja Rosda Karya.

Hamid, Hamdani \& Saebani, B. Ahmad. 2013. Pendidikan Karakter Perspektif Islam. Bandung : Pustaka Setia.

Muslich, Masnur. 2011. Pendidikan Karakter Menjawab Tantangan Krisis Multidimensional. Jakarta : Bumi Aksara.

Samani, Muchlas \& Hariyanto. 2014. Konsep dan model pendidikan karakter. Bandung : Remaja Rosdakarya Offset.

Kesuma, dkk. 2012. Pendidikan Karakter kajian teori dan praktik di sekolah. Bandung : Remaja Rosdakarya Offset.

Kesuma. 2019. Pengertian Pendidikan Karakter dan Aspeknya Menurut Para Ahli. Blog Universitas Psikologi.Online : https://www.universitaspsikologi.com/2019/11/pengertian-pendidikankarakter-dan-aspek-karakter-menurut-ahli.html. Diakses tanggal 10 Mei 2020.

Rochayati, Umi. \& Wardani, Ratna. 2018. Model Pembelajaran Karakter Kerja Di Sekolah Menengah Kejuruan. Jurnalkependidikan, Volume 2, Nomor 1, Mei 2018, Halaman 116-127.

Irwansa, A. 2015. Analisis Pelaksanaan Tata Tertib Sekolah Pada Siswa Di Smk Negeri 1 Makassar. Skripsi. Dipublikasikan di Jurnal Tomalebi Volume II, Nomor 1, Maret 2015. Online : https://ojs.unm.ac.id/tomalebbi/article/view/1670/716. Diakses tanggal 10 Mei 2020. 